УДК 784.5:78.034.7“16”

DOI: https://doi.org/10.33643/kmus.2019.58.02

Галина Омельченко-Агай Кухі, здобувач кафедри старовинної музики Наиіональної музичної академії Украӥни ім. П. І. Чайковського https://orcid.org/0000-0002-5561-9594 galina-aghaie@yandex.ua

Galyna Omelchenko-Aghaie Koohi, Postgraduate at the Early Music Department, Ukrainian National Tchaikovsky Academy of Music https://orcid.org/0000-0002-5561-9594 galina-aghaie@yandex.ua

\title{
СОЛЬНА КАНТАТА БАРОКОВОЇ ДОБИ: ПРОБЛЕМА ВИЗНАЧЕННЯ ЖАНРОВОГО ІНВАРІАНТУ
}

Актуальність теми. Статтю присвячено жанру сольної кантати, який $є$ найменш дослідженим та невиокремленим із групи кантатних жанрів. Метою cmammi $\epsilon$ визначення особливостей жанру через визначення його інваріанту. Методологія дослідження полягає у використанні аналітичного та історичного методів дослідження, а також методу жанрового аналізу. Наукова новизна статmi - у виявленні та обгрунтуванні основних параметрів жанрового інваріанту сольної кантати доби бароко, що може стати основою для дослідження перетворень жанру в наступних історичних епохах. Висновки. Жанру сольної кантати доби бароко властиві параметри, що дозволяють стверджувати про його самостійність та самобутність.

Ключові слова: сольна кантата, жанр, жанровий інваріант.

Omelchenko-Aghaie Koohi Galyna. Baroque solo cantata: the problem of determining the genre invariant. Relevance of the study. The article is devoted to the genre of solo cantata, which is the least studied, as well as unselected from the group of cantata genres. The genre's emergence and genesis takes place on the territory of modern Italy at the beginning of the $17^{\text {th }}-$ first half of the $18^{\text {th }}$ centuries, and its evolution lasts about four centuries and continues in our time. Since the end of the $18^{\text {th }}$ century the solo cantata is shifted from the central position to the periphery of the genre fund, but does not disappear, but on the contrary continues to exist, changing in accordance with the new eras, styles and trends. That is why the actual task is an attempt to determine the genre invariant of the solo cantata. Thus, the main objective of the article is to determine the characteristics of the genre, through the description of 
its invariant. The research methodology consists of using analytical and historical methods, as well as collecting and accumulating musical material in order to study in detail specific examples of solo cantatas. To achieve this goal, solo cantatas created in the Baroque era were used and analyzed, since it was at this stage that the genre acquired the most perfect forms and could serve as a starting point in the study of its transformation in accordance with the following historical eras. In addition, the method of genre analysis was used. The scientific novelty of the article consists in identifying and substantiating the main parameters of the genre invariant of the baroque solo cantata, which can form the basis of research on the transformation of the genre of the following historical eras. Findings. The genre of solo cantata of the Baroque epoch has a number of parameters that make it possible to speak about its independence and originality.

Key words: solo cantata, genre, genre invariant.

Омельченко-Агай Кухи Галина. Сольная кантата эпохи барокко: проблема определения жанрового инварианта. Актуальность темь. Статья посвящена жанру сольной кантаты, который является наименее исследованным, а также невыделенным из группы кантатных жанров. Становление и зарождение жанра происходит на территории современной Италии в начале XVII - первой половине XVIII ст., а его эволюция длится около четырех столетий и продолжается в наше время. С конца XVIII ст. сольная кантата смещается с центральной позиции на периферию жанрового фонда, однако не исчезает, a, напротив, продолжает свое существование, изменяясь в соответствии с новыми эпохами, стилями и направлениями. Именно поэтому актуальным заданием является попытка определить жанровый инвариант сольной кантаты. Таким образом, цель cmambu заключается в определении особенностей жанра через описание его инварианта. Методология исследования состоит в использовании аналитического и исторического методов, а также в сборе и накоплении музыкального материала с целью детального изучения конкретных примеров сольных кантат. Для достижения поставленной цели были использованы и проанализированы сольные кантаты, созданные в эпоху барокко, поскольку именно на этом этапе жанр приобретает наиболее совершенные формы и может служить отправной точкой в исследовании его трансформации в соответствии со следующими историческими эпохами. Кроме того, для определения инварианта сольной кантаты была использована методика жанрового анализа. Научная новизна статьи состоит в выявлении и обосновании основных параметров жанрового инварианта сольной кантаты барокко, которые могут лечь в основу исследований о преобразовании жанра следующих исторических эпох. 
Bbывоbы. Жанру сольной кантаты эпохи барокко присущ ряд параметров, позволяющих говорить о его самостоятельности и самобытности.

Ключевые слова: сольная кантата, жанр, жанровый инвариант.

Сольна кантата - один із групи кантатних жанрів, що належить до камерно-вокальної музики, історія розвитку якого налічує понад чотириста років. Зародження сольної кантати відбулося в добу бароко на території сучасної Італії. Саме протягом XVII - першої половини XVIII ст. відбувається стрімке становлення жанру, пов'язане 3 іменами найвидатніших композиторів доби бароко - Дж. Каріссімі, А. Скарлатті, Г. Генделя $[15$, с. 76]. Починаючи 3 кінця XVIII ст. сольна кантата зміщується із центральної позиції на периферію жанрового фонду, однак не зникає, а продовжує існувати, змінюючись відповідно до нових стилів та напрямків [14, с. 694].

Актуальність теми дослідження полягає у спробі визначити жанровий інваріант сольної кантати, оскільки на сьогодні цей жанр не дістав детального вивчення в музикознавчій літературі, а тому не має чіткого та конкретного формулювання. Окрім того, сольну кантату не виокремлено досі 3-поміж інших кантатних жанрів, таких як хорова кантата, велика вокально-хорова кантата, камерна кантата та ін. Таким чином, незважаючи на постійну зацікавленість кантатними творами, мало хто 3 дослідників розрізняє зазначені жанри. Така своєрідна плутанина підкріплена науковими поглядами радянського періоду відносно жанру кантати в цілому (А. Терещенко [10], А. Хохловкіної [12], а також статтею А. Левіка [5]). У більш сучасних роботах переважно розглядаються особливості камерної кантати (Н. Копитько [4]) та ii поширення серед українських композиторів останньої третини XX ст. (М. Ярко [13; 14]). Відзначимо також відсутність спеціальних досліджень, присвячених сольній кантаті, і серед іншомовних джерел. Тому в даному дослідженні використані матеріали розвідок із довідникової іноземної літератури (музичний словник Гроува [7; 14], М. Кеннеді [15]).

Таким чином, детальне вивчення саме жанру сольної кантати, а також спроба виявлення іiі інваріанту становить новизну дослідження та загострює його актуальність.

Мета й завдання статті полягають у поясненні особливостей жанру сольної кантати через ряд параметрів та у формулюванні визначення жанру.

Методи дослідження. Для досягнення поставленої мети було обрано та проаналізовано сольні кантати, написані за доби бароко, оскільки саме на цьому етапі жанр набуває найбільш довершеної форми та може слугувати 
відправною точкою в дослідженні його трансформації протягом наступних історичних епох. Поняття «жанровий інваріант», вперше запропоноване М. Арановським [1], знаходить продовження в розробках Є. Назайкінського [8] та І. Тукової [11]. Чітку схему виявлення конкретного жанрового інваріанту за допомогою аналізу низки параметрів, які найбільш точно відображають його сутність, запропоновано в дисертаційному дослідженні «Функціонування інструментальних жанрових моделей західноєвропейського бароко в українській музиці другої половини ХХ ст.» I. Тукової [11]. Для визначення жанрового інваріанту дослідниця виокремлює параметри, що входять до двох основних рівнів:

«Функціональний рівень:

- життєва функція (або соціально-культурна) - умови побутування конкретного жанру;

- склад виконавців.

Семантично-композиційний рівень:

- жанровий зміст;

- композиційна схема;

- засоби жанрової виразності (найбільш характерні для даного конкретного жанру)» $[11$, с. 6].

Результати. Проведемо жанр сольної кантати крізь рівні аналізу жанрового інваріанту та спробуємо виявити характерні саме для нього параметри.

\section{Функціональний рівень. Соціально-культурна функція}

Жанр сольної кантати почав формуватися на батьківщині опери, в Італії, пізніше поширився в різних країнах. Тому ранні зразки сольних кантат часто називають італійськими кантатами.

За доби бароко, як відомо, відбувалися масштабні зміни як на загальному мистецькому рівні, так і на рівні композиторського мислення. Провідне місце зайняли музично-театральні жанри, чому сприяли характерні ознаки бароко: тяжіння до драматичної експресії та синтезу різних видів мистецтва. Одним із проявів цих змін став процес формування сольних вокальних жанрів: опери, сольної кантати й арії як найменшої складової одиниці. Спробуємо окреслити основні, на нашу думку, причини таких змін.

Найголовніша - усвідомлення цінності людського голосу, його індивідуальної краси. Вже в XVI ст. відбувається поступове виокремлення сольних голосів із хорової (меса) та ансамблевої (мадригали, мотети) маси. Усвідомлення сольного співу як самостійної галузі мистецтва сприяло культивуванню особливої виконавської манери, що у XVIII ст. оформлюється в мистецтво (а надалі - у школу та стиль) bel canto. 
В. Конен зазначає, що співак, котрий був лише «голосовою одиницею», елементом складної багатотембрової структури хору, став усвідомлюватись як артистична індивідуальність, головний виразник ідеї (у музиці ж виразником такої ідеї стала чуттєво-прекрасна мелодика, що мала значні виразові можливості) [3, с. 76].

I. Драч зазначає, що мистецтво сольного вокального виконавства, яке виникло завдяки пошукам «нових форм співу», змінило процес інтонування і стало розглядатися як окреме явище. В. Галілеї, Я. Пері, Дж. Каччіні, К. Монтеверді - митці, котрі хронологічно належали до покоління «універсальних» ренесансних особистостей. Саме їм як співакам, композиторам та вченим належить зміна художніх пріоритетів та відхід від тотального багатоголосся і створення насиченої виразної музичної декламації. Таке ставлення до співу взагалі оформлюється в особливу концепцію «людини, яка співає», що стає перехідною спадковою ланкою від ідей Ренесансу, де людина уявлялася всемогутньою, всебічно обізнаною, талановитою в усьому, такою, що поєднує в собі прекрасне, добре та звитяжне. Ці ідеї надзвичайно вдало підхопило бароко. Можливо, вперше в історії музики починають фіксуватись імена не тільки співаківкомпозиторів, а й співаків - лише виконавців. Зокрема, згадаємо найвідоміших - П. Тозі, Ф. Пістоккі, В. Аркілеї.

Нова форма співу могла бути доступною лише «відшліфованим» голосам, тобто «природний матеріал» мав перетворитися на досконалий інструмент [2, с. 66-73].

У «новому співі» фрагменти творів із кантиленною мелодичною лінією поєднувались із елементами віртуозного виконавства, завдяки чому з'явилися нові вимоги до співака-соліста. Зайняті в мадригалах співаки та співачки володіли, як правило, невеликими голосами в діапазоні децими. Нові ж співаки, аби задовольнити потреби композиторів, почали розширяти діапазон голосу до обсягу 1,5 октави. У зв'язку з цим виникає нова техніка подачі голосу.

Основною особливістю співу стала подача голосу «вперед», 3 інтенсивним використанням резонаторів носової порожнини, що надавало звуку яскравого, блискучого забарвлення та посилювало тривалість звучання. Зріс попит на високотеситурні голоси. Можна прослідкувати зміну ставлення слухацької аудиторії та композиторів до високого регістру чоловічих та жіночих голосів. Наприклад, у монографії, присвяченій мистецтву bel canto, О. Стахевич реконструює процес освоєння регістрів людського голосу. Із середини XVII ст. значну різницю в тембрах грудного та фальцетного регістрів у чоловічих голосів було використано як 
позитивний ефект у сольному виконавстві. У розвитку жіночих голосів, зокрема сопрано (в якому так зване фальцетне звучання було природним), почався процес розширення діапазону грудного регістру [9, с. 20, 22].

Освоєння тембрів людського голосу стало головним чинником зародження та стрімкого розвитку вокального мистецтва співаків-кастратів. Окрім широкого діапазону та розвинених легенів, вони вражали публіку силою звучання, що могла заповнити збільшений простір концертного залу, тембром голосу, який можна порівняти зі звучанням солюючої труби. Жіночі високі голоси частіше асоціювалися зі звучанням флейти (легкість, «польотність»), скрипки (легатність, кантилена), а низькі - 3 віолончеллю (найбільше зближення з тембром людського голосу).

У зв'язку з таким освоєнням тембрів, розвиток вокального мистецтва рухався у двох напрямах. Як зазначає О. Стахевич, з початку XVII століття плавне інтонування мелодії та використання технічних можливостей голосу втілюються у два основні виконавські стилі- кантиленний та віртуозний (колоратурний) [9, с. 24].

Віртуозність виконання сольних партій, уміння заворожити слухачів плавністю, легатністю звучання, «інвенцією» розуму в мистецтві імпровізації стають найвищими проявами майстерності співака та особливими видами творчості виконавця. До речі, віртуоз - «virtu»- у перекладі з латини означає «звитяга». Музикант, який володіє технічною майстерністю, прагне продемонструвати іiі на сцені. Момент сольного виступу, усвідомлення себе як основної рушійної сили розвитку, вимагає від соліста особливої зібраності, сміливості, внутрішнього відчуття технічної «озброєності», уміння володіти ситуацією, аби виступити перед публікою. Мета такого «подвигу» - отримати визнання тисячі слухачів цілого залу.

Паралельно 3 освоєнням та розвитком мистецтва сольного співу відбуваються зміни, пов’язані з місцем виступу музикантів-виконавців. На початку XVII ст. в Італії простір приміщення, в якому проводяться музичні вистави, починає диференціюватися на відокремлені частини: простір сцени та простір глядацької аудиторії. 3'являється спеціальне слово «ambiente» (3 італ. - «навколишнє середовище»), яке означає виокремлений простір, що відділяє виконавців від публіки [6, с.61]. Таким чином, з одного боку, починає формуватись взаємодіюча ланка «виконавець - слухач»; з іншого складові цієї ланки певною мірою протиставляються.

Збільшення кількості слухачів веде зі свого боку до розширення масштабів концертної аудиторії. Аби краще відчути їх зміну, згадаємо зображення концертів на ренесансних картинах, де можна виявити чітку закономірність композиції: звуженість простору, групування музикантів 
навколо столу (що є майже обов'язковим елементом зображення), а слухачів - безпосередньо біля музикантів. Однак уже на початку XVII ст. кількість глядачів вимагає більш організованого простору, аби споглядати музичне дійство міг кожний із присутніх у залі. Тому особливістю організації концертного залу стає трапецієподібне або прямокутне розташування слухачів відносно сцени, що створює горизонтальний вектор напрямку звуку, якому нічого не перешкоджає досягати найвіддаленішої зони слухацької аудиторії.

Отже, соціально-культурний параметр жанру виражається в тому, що сольна кантата $\epsilon$ свого роду одним із жанрів-постулатів нової естетикокультурної парадигми. Зокрема, за допомогою сольної кантати затверджується спочатку виразна сольна декламація, яка згодом переросте, з одного боку, у сформовану виконавську систему bel canto, а з іншого - в естетичну потребу у виразній, характерній та чітко оформленій мелодії як виразнику головної ідеї твору та його ключовому структурному елементі. Обидва шляхи розвитку ідеї сольного співу, представленої в сольній кантаті, будуть активно використовуватись і після доби бароко.

Наступний параметр функціонального рівня - виконавський склад стає логічним продовженням попереднього. Головною ознакою сольної кантати, що, до речі, закріпилася й у назві жанру, стає принцип сольності. Його можливо прослідкувати в декількох напрямах. Найперший - це наявність соліста-вокаліста який $є$ репрезентантом персонажу. Дискретність сюжетної лінії в сольній кантаті долається через розповідь про події, тому соліст може одночасно нести навантаження як героя твору, так і оповідача. Якщо у зв’язку з більш розгалуженою сюжетною лінією постає потреба в декількох персонажах (наприклад, у сольних кантатах Г. Генделя їх кількість досягає чотирьох), принцип сольності виявляється в чіткій регламентації висловлювань героїв. Вибір сценічної ситуації здійснюється на користь послідовності сольних висловлювань, такі форми як дуети, терцети тощо навмисне уникаються. Другий напрям передбачає використання двох найбільш поширених форм сольного висловлювання apiï та речитативу. Третій - це посилення принципу сольності через використання тембрової драматургії, зокрема виокремлення із загального складу супроводу солюючих інструментів, які посилюють емоційне переживання героя, відтіняють технічні складності у вокальній партії, подекуди навіть «змагаючись» із солістом-вокалістом.

Найбільш характерною рисою для сольної кантати доби бароко $є$ синтетична природа жанру, саме тому, окрім музичного компоненту, обов'язковим $є$ i текстово-поетичний. Завдяки текстовій складовій, яка 
була написана переважно італійською, сольні кантати доби бароко також називають італійськими сольними кантатами.

Наступним у визначенні жанрової моделі $\epsilon$ семантикокомпозиційний рівень, одним із показників якого є жанровий зміст.

Для сольної кантати чинником, що обумовлює зміст жанру, є його світська природа, яка насамперед проявляється в існуванні сюжету не пов'язаного із церковною тематикою. Зародження та становлення жанру відбувається під впливом нових естетичних поглядів стосовно музичного мистецтва, які були сформульовані на мистецько-філософських зібраннях доби бароко, найвідомішим з яких була Флорентійська камерата. Одними 3 вирішальних ідей, що, як відомо, вплинули на зародження жанрів опери та сольної кантати, стали: прагнення відродити античну трагедію та заперечення поліфонії.

Звернення до античної трагедії стало вирішальним для оформлення кола сюжетів, основою для яких слугували давньогрецькі міфи, а персонажами були багаточисленні боги та герої. Сюжетні перипетії та відносини між персонажами в обраному сюжеті зазвичай ототожнювалися iз сучасними, відомими колу слухачів особистостями та подіями, а переживання, представлені в сюжеті, були абсолютно «земними», мирськими, зрозумілими кожному.

Саме тому для сольної кантати доби бароко характерними є наявність сюжету (або натяк на сюжет через ім'я персонажа/персонажів), втілення якого в повному об'ємі не є обов'язковим. Частіше 3 одного сюжету виокремлюється найбільш яскравий фрагмент, який композитор використовує як основу для обрання персонажів, послідовності номерів і текстів.

Варто зазначити, що в жанрі сольної кантати можливе використання духовного тексту, який скоріше можна віднести до паралітургічного. Це можуть бути поетичні та прозові тексти латиною, в яких більш вільно порівняно 3 канонічними текстами висвітлюються біблійні сюжети. 3 точки зору музичного втілення сольна духовна кантата повністю збігається за композиційним та виконавським параметрами зі світською.

Друга головна ідея Флорентійської камерати - заперечення поліфонії - підкреслює світську ознаку жанру сольної кантати. Адже для того, аби вразити слухача, отримати його реакцію на представлених персонажів та події, що відбуваються в сольній кантаті, необхідно чітко та зв'язно донести обраний текст твору. Для досягнення цієї мети, спираючись на спогади про давньогрецьку монодію, флорентійці запропонували так званий речитативний стиль співу 3 максимально деталізованою вимовою слова - музичну декламацію, в якій мелодичні 
звороти, ритм і темп співу повністю підпорядковані тексту й повинні відображати та посилювати його емоційне забарвлення.

Параметр композиційної схеми сольної кантати доби бароко представлений через цикл як завершену, замкнену послідовність взаємно підпорядкованих частин. Доречно зауважити, що тривалість циклу зазвичай коливається від 10 до 30 хвилин. Особливістю є його наповнення, а саме послідовність речитативів (R) secco, accompagniatto та арій (A). До зазначених частин можуть додаватися суто інструментальні частини типу інтродукції, серединного та заключного ритурнелів. Кількість частин в одному циклі починається від чотирьох (наприклад, $\mathrm{R}-\mathrm{A}-\mathrm{R}-\mathrm{A}$ ) та може бути довільно збільшена в залежності від обраного сюжету.

Висновки. Отже, завдяки представленому аналізу стає зрозумілим, що сольна кантата доби бароко має особливі параметри інваріанту, що якісно відрізняють їі від інших зразків кантатного жанру. Серед них:

- соціально-культурна функція - жанр-постулат нової культурної парадигми;

- склад виконавців - соліст-вокаліст (або до чотирьох солістів), інструментальний супровід;

- жанровий зміст - наявність поетичного або прозового світського (та духовного) тексту, сюжетність;

- композиційна схема - циклічна композиція (складові частини: інструментальний вступ, арія, речитатив, ритурнелі).

3 огляду на обидва функціональні параметри, соціально-культурний та виконавський, можна з упевненістю стверджувати виправданість назви жанру «сольна кантата», яку часто підміняють більш узагальненою назвою «камерна кантата». Нагадаємо, що за доби бароко частина назви твору «da camera» використовувалась до будь-якої світської музики, на противагу церковній. Пізніше до камерних творів почали відносити ті, що мали обмежену кількість виконавців (від двох до десяти) та слухачів, на відміну від симфонічної музики. Таких обмежень та поділу не було за доби бароко, тому що не було протиставлення концертно-естрадного та камерного музикування, це не було актуальним на той час. Особливого значення камерність як принцип набуває у XIX та XX століттях. Зокрема, під таким визначенням передбачається своєрідна інтимність висловлювання, комунікативна інтровертність, втілення процесу самопізнання та своєрідний діалог із собою. Окрім того, у ХХ ст. твори, які можна віднести до камерної музики, є втіленням ідеї людяності, повернення до мистецтва, що зорієнтоване на живе сприйняття та співпереживання, на противагу творам, які вражають технічно, однак 
залишаються в площині «мистецтва для мистецтва». Саме тому стає зрозуміло, що використання частини назви «da camera» щодо сольної кантати є досить суперечливим і потребує додаткових пояснень. До того ж у самих нотних зразках сольних кантат композиторів доби бароко назва «da camera» майже не зустрічається, що також є важливою ознакою та демонструє загальну тенденцію в розумінні жанру.

Визначення жанрового інваріанту сольної кантати доби бароко дозволяє впізнавати музичні зразки, які не дістали власної назви, однак відповідають параметрам інваріанту. Крім того, чітке його формулювання дозволяє зрозуміти трансформації та перетворення жанру сольної кантати, що зустрічаються в наступних епохах.

1. Арановский М. Структура жанра и современная ситуация в музыке // Музыкальный современник. Вып. 6. Москва : Советский композитор, 1987. С. 5-44.

2. Драч И. Художественная выразительность итальянского бельканто как системы музыкального интонирования // Из истории национальных оперных школ. Киев : Киевская госконсерватория, 1988. С. 64-76.

3. Конен В. Театр и симфония. Роль оперы в формировании классической симфонии. Москва : Музыка, 1968. 349 с.

4. Копитько Н. Камерная кантата как эстетический феномен// Старонкі гісторыі беларускай музыкі. Вып. 8. Мінск, 2005. С. 196-203.

5. Левик Б. Кантата // Музыкальная энциклопедия : в 6 т. / гл. ред. Ю. Келдыш. Т. 2. Москва : Сов. энциклопедия, 1974. С. 697-700.

6. Лобанова М. Западноевропейское музыкальное барокко: проблемы эстетики и поэтики. Москва : Музыка, 1994. 318 с.

7. Музыкальный словарь Гроува / пер. с англ., ред. и дополн. Л. Акопяна. Москва : Практика, 2001. 1095 с.

8. Назайкинский Е. Стиль и жанр в музыке. Москва: Гуманитарный издательский центр ВЛАДОС, 2003. 248 с.

9. Стахевич А. Искусство bel canto в итальянской опере XVII-XVIII веков. Харьков : ХДАК, 2000. $156 \mathrm{c.}$

10. Терещенко А. Українська радянська кантата і ораторія (1917-1945). Київ : Наукова думка, 1980. 216 с.

11. Тукова I. Функціонування інструментальних жанрових моделей західноєвропейського бароко в українській музиці другої половини ХX ст. : автореф. дис. ... канд. мистецтвознавства : 17.00.03. Київ, 2003. 19 с.

12. Хохловкина А. Советская оратория и кантата. Москва : Музгиз, 1955. $147 \mathrm{c}$.

13. Ярко М. Жанрово-стильові особливості сучасної камерної кантати (на матеріалі творчості українських композиторів 70-80 pp. ХХ ст.) : автореф. дис. ... канд. мистецтвознавства : 17.00.02. Київ, 1991. 16 с.

14. Fortune N., Timms K., Boyd M., Krummacher Fr., Tanley D. Cantata// The New Grove Dictionary of Music and Musicians. $6^{\text {th }} \mathrm{ed} . / \mathrm{ed}$. by S. Sadie. London : Macmillan Publishers, 1980. Vol. 3. P. 694-718. 
15. Kennedy M. Cantata // The Oxford Dictionary of Music. $2^{\text {nd }}$ ed. Oxford; New York : Oxford University Press, 2006. P. 976.

16. Miller R. On the Art of Singing. New York ; Oxford : Oxford University Press, 1996. 336 p.

\section{References}

1. Aranovsky, M. (1987). The structure of the genre and the current situation in music. Muzykalnyy sovremennik, 6, pp. 5-44 [in Russian].

2. Drach, I. (1988). Artistic expressiveness of the Italian belcanto as a system of musical intonation. Iz istorii natsionalnykh opernykh shkol, pp. 64-76 [in Russian].

3. Konen, V. (1968). Theater and Symphony. The role of opera in the formation of the classical symphony. Moscow: Muzyka [in Russian].

4. Kopitko, N. (2005). Chamber cantata as an aesthetic phenomenon. Staronki historyi bielaruskaj muzyki, 8, pp. 196-203 [in Belorussian].

5. Levik, B. (1974). Cantata. In: Musical Encyclopedia. Vol. 2. Moscow: Sovetskaya entsiklopediya, pp. 697-700 [in Russian].

6. Lobanova, M. (1994). Western European musical baroque: problems of aesthetics and poetics. Moscow: Muzyka [in Russian].

7. Grove, G. (2001). Grove Music Dictionary. L. Akopyan (Ed., trans.). Moscow: Praktika [in Russian].

8. Nazaykinskiy, Y. (2003). Style and genre in music. Moscow: Gumanitarnyy izdatelskiy tsentr VLADOS [in Russian].

9. Stakhevich, A. (2000). Art of bel canto in Italian opera of XVII-XVIII centuries. Kharkov: KhDAC [in Russian].

10. Tereshchenko, A. (1980). Ukrainian Soviet Cantata and Oratorio (1917-1945). Kyiv: Naukova dumka [in Ukrainian].

11. Tukova, I. (2003). Functionalization of instrumental genre models of the West European baroque in Ukrainian music of the second half of the twentieth century. Extended abstract of $\mathrm{PhD}$ thesis. Kyiv [in Ukrainian].

12. Khokhlovkina, A. (1955). Soviet oratorio and cantata. Moscow: Muzgiz [in Russian].

13. Yarko, M. (1991). Genre-style features of modern chamber cantata. Based on the works of Ukrainian composers of 70-80s of the twentieth century. Extended abstract of $\mathrm{PhD}$ thesis. Kyiv [in Ukrainian].

14. Fortune, N., Timms, K., Boyd, M., Krummacher, Fr., Tanley, D. (1980). Cantata. In: S. Sadie (Ed.). The New Grove Dictionary of Music and Musicians. Vol. 3. London: Macmillan Publishers, pp. 694-718 [in English].

15. Kennedy, M. (2006). Cantata. In: The Oxford Dictionary of Music. 2nd ed. Oxford; New York: Oxford University Press, p. 976 [in English].

16. Miller, R. (1996). On the Art of Singing. New York; Oxford: Oxford University Press [in English]. 